\title{
Trophic State and Microorganisms Community of Major Sub-Basins of the Middle Rio Doce Basin, Southeast Brazil
}

\author{
Mauricio Mello Petrucio ${ }^{1,2 *}$, Adriana Oliveira Medeiros ${ }^{3}$, Carlos Augusto Rosa ${ }^{3}$ and \\ Francisco Antônio Rodrigues Barbosa ${ }^{1,2}$ \\ ${ }^{I}$ Doutorando PPG-ERN/UFSCar; Centro Universitário do Leste de Minas Gerais - UnilesteMG; Laboratório de \\ Ecologia; Av. Pres. Tancredo de Almeida Neves, 3500; 35170-056; Coronel Fabriciano - MG - Brasil. \\ ${ }^{2}$ Universidade Federal de Minas Gerais; ICB; Departamento de Biologia Geral; Laboratório de Limnologia; \\ 30161-970; Belo Horizonte - MG - Brasil. ${ }^{3}$ Laboratório de Ecologia e Biotecnologia de Leveduras; Departamento \\ de Microbiologia; ICB; Universidade Federal de Minas Gerais; C. P. 486; Belo Horizonte - MG - Brasil
}

\begin{abstract}
Total phosphorus concentration was used to define the trophic state of the main sub-basins of the middle Rio Doce, in Minas Gerais State (southeast Brazil) and physical, chemical, and microbiological variables of water were analyzed during 2000 to 2001. The study evaluated changes in water quality caused by seasonality and human activities. Water temperature, conductivity, $\mathrm{pH}$, total alkalinity, dissolved oxygen, and concentrations of $\mathrm{NH}_{4}-\mathrm{N}$, $\mathrm{NO}_{2}-\mathrm{N}, \mathrm{NO}_{3}-\mathrm{N}$, total-N, $\mathrm{PO}_{4}-\mathrm{P}$, total-P, DOC, and chlorophyll-a were measured in seven rivers stretches (sampling stations). Total yeasts, faecal and total coliforms, and heterotrophic bacteria were also determined. The studied areas were considered to be under oligotrophic to eutrophic conditions. The variables that presented highest positive correlation with faecal coliforms were total-P and total- $N$, and heterotrophic bacteria density was identified as a good parameter to differentiate the ecosystems. These results suggested the inclusion of the trophic level and the distinct activities within a watershed as important elements when proposing conservation and restoration areas.
\end{abstract}

Key words: Microorganisms, phosphorus, rivers, trophic state

\section{INTRODUCTION}

The disordered human occupation of the drainage basins has drastically modified the aquatic ecosystems mainly by accelerating the deposition of nutrients in water bodies. Due to the increasing need to use water resources in the last decades, the evaluation of eutrophication impact in lotic ecosystems is imperative (Kelly and Whitton, 1998; Wetzel, 1991). Although lotic ecosystems are abundant in Brazil, they have not been studied enough and there are only a few data available that can support the definition for conservation and management policies (e. g. Barbosa et al., 1997; Barbosa and Callisto, 2000). Water uses and socio-economic aspects of the drainage basin are fundamental elements for the understanding of the ongoing processes within aquatic ecosystems and for definition of strategies for conservation and management politicies of aquatic environments (Tundisi and Barbosa, 1995).

Inputs of allochthonous material from industrial

\footnotetext{
*Author for correspondence
} 
and domestic effluents, associated with other human activities in densely occupied watersheds have been changing significantly the water quality as well as the ecological conditions of the rivers. This reflects considerably on the composition and structure of aquatic communities and their interactions, as demonstrated previously by Barbosa et al. (1997) for the major sub-basins of the middle Rio Doce, in the State of Minas Gerais. Thus, characterization of the major nutrients levels, trophic state, and composition and structure of aquatic communities constitutes essential tools to detect different types of impact as a way to propose mitigation and conservation measures.

Traditionally, the characterization of trophic status of an aquatic ecosystem involves determination of nutrient concentrations, mainly phosphorus and nitrogen, and can be complemented with information on variables such as chlorophyll- $a$ concentration and water transparency (OECD, 1982; Salas and Martino, 1991). The quality of the water has been routinely evaluated by measuring physical and chemical variables, without considering the important role played by the existing aquatic biota. The presence of bacteria of the coliform group is considered an indicative of potencial health risks and is a widely used microbial method for monitoring water quality (Greenberg et al., 1998). Several studies have focused on the occurrence of yeasts related to wastewater (Simard, 1971; Hagler and Mendonça-Hagler, 1981) showing that yeast counts can be a monitoring method that can complement coliform counts also reflecting eutrophication (Hagler and Ahearn, 1997). Salas and Martino (1991) have used the concentration of total phosphorus to define the level of human impact on aquatic environments and consider it as the most appropriate variable index for tropical environments. However, its application to lotic environments still needs further and conclusive studies.

In an attempt to identify, among the components of the existing biota, potential indicators of the trophic status of the water, the present study had as the major objective to characterize the trophic status of the main sub-basins of the middle Rio Doce using physical, chemical and microbiological variables. This study also aimed at determining changes in water quality caused by human activities in order to propose the including of trophic indices to evaluate the restoration of degraded areas.

\section{STUDY AREA}

This study was carried out in the medium stretch of the Rio Doce basin, State of Minas Gerais, southeast Brazil. Water samples were collected in 7 stations (table 1), representative of the sub-basins of the rivers, with different order number according to the method of Strahler (Gordon et al., 1992).

These ecosystems (Fig. 1) were chosen because they permitted comparative studies, given that strong differences were found in the environmental characteristics of the sampling stations, due to different degrees of human activities (Paula et al., 1997).

The Caraça river flows almost entirely inside an Environmental Protection Area (Caraça Natural Park) and it is considered as a "reference" to the basin, given it is submitted to minimum anthropogenic activity. The other rivers are submitted to different types of human influence, such as cattle rising, mining, domestic and industrial effluents. Extensive areas with Eucalyptus spp plantations are found in the basin of some environments (ex.: Santa Bárabara and Piracicaba).

Table 1 - Geographyc localization and order number of the 7 sampling station in the middle Rio Doce basin.

\begin{tabular}{c|c|c}
\hline River & Location & Order \\
\hline Caraça & $20^{\circ} 06^{\prime} 00^{\prime \prime} \mathrm{S} 43^{\circ} 29^{\prime} 09^{\prime \prime} \mathrm{W}$ & $2^{\text {nd }}$ \\
Santa Barrbara & $19^{\circ} 50^{\prime} 01^{\prime \prime} \mathrm{S} 43^{\circ} 21^{\prime} 14^{\prime \prime} \mathrm{W}$ & $5^{\text {th }}$ \\
Peixe & $19^{\circ} 44^{\prime} 35^{\prime \prime} \mathrm{S} 43^{\circ} 01$ ' $16^{\prime \prime} \mathrm{W}$ & $3^{\text {rd }}$ \\
Severo & $19^{\circ} 36^{\prime} 57^{\prime \prime} \mathrm{S} 42^{\circ} 50^{\prime} 50^{\prime \prime} \mathrm{W}$ & $6^{\text {th }}$ \\
Piracicaba & $19^{\circ} 29^{\prime} 25^{\prime}, \mathrm{S} 42^{\circ} 31^{\prime} 08^{\prime \prime} \mathrm{W}$ & $3^{\text {rd }}$ \\
Ipanema & $19^{\circ} 28^{\prime} 14^{\prime \prime} \mathrm{S} 42^{\circ} 32^{\prime} 01^{\prime \prime} \mathrm{W}$ & $7^{\text {th }}$ \\
Doce & $19^{\circ} 19^{\prime} 12^{\prime \prime} \mathrm{S} 42^{\circ} 21^{\prime} 52^{\prime \prime} \mathrm{W}$ & \\
\hline
\end{tabular}


Ipanema river has great part of its course canalized and receive domestic and industrial effluents and Rio Doce receives discharges of all other rivers. The sampling station in this river was localized downstream the Escura falls, which according to Barbosa et al. (1997) is very important to recover its water quality, mainly through an efficient re-oxygenation of the water.

\section{METHODS}

Measurements and samplings of the above described rivers were done during the rainy and dry seasons of 2000 and 2001 (January and August, respectively). The water temperature, electric conductivity, $\mathrm{pH}$ and dissolved oxygen were measured "in situ", with a multiprobe (Horiba, mod. U-22). At these places, water samples were collected to determine the contents of dissolved organic carbon (TOC-500 Shimadzu); total nitrogen, nitrate-nitrogen, nitrite-nitrogen and total alkalinity (Mackereth et al., 1978); ammonium-nitrogen (Grasshoff, 1976); total phosphorus and soluble reactive phosphorus (Golterman et al., 1978). Chlorophyll- $a$ concentration was obtained after filtration of total samples in Schleicher and Schuell GF 50-A membranes and determination according to Lorenzen (1967).

For microbiological analyses, the surface water samples were taken directly into sterile glass bottles and returned to the lab in ice within $8 \mathrm{~h}$ for processing. Total and faecal coliforms were determined using standard most probable number methods (MNP) and heterotrophic bacteria counts were made using the pour plate method on NWRI agar (Heterothrophic plate count agar - HPCA) (Greenberg et al., 1998). For total and faecal coliforms determination, water sample dilutions $10^{-1}, 10^{-2}$ and $10^{-3}$ were used. For the yeasts counts (CFU) aliquots of 0.1 $\mathrm{ml}$ of the samples were plated in triplicates on YM agar (1.0\% glucose, $0.5 \%$ peptone, $0.3 \%$ yeasts extract, $0.3 \%$ malt extract, $2.0 \%$ agar, 10 $\mathrm{mg}$ chloramphenicol). Plates were incubated at $25^{\circ} \mathrm{C}$ and yeasts counts were obtained after 3 to 5 days as described in Kurtzman and Fell (1998).

Linear correlation analyses was used to verify the influence of abiotic variables on microorganisms community. Principal component analysis (PCA) was used in the treatment of the abiotic and biotic data. The following variables were not transformed and used in the matrix: temperature, $\mathrm{pH}$, electrical conductivity, dissolved oxygen, total alkalinity, Total-P, Total-N, total and faecal coliforms, yeasts and heterotrophic bacteria counts.

\section{RESULTS AND DISCUSSION}

During the sampling periods, precipitation varied between $0.0 \mathrm{~mm}$ (July 2000, 2001) and $59.2 \mathrm{~mm}$ (January 2000) (Data obtained from Instituto Mineiro de Gestão das Águas - IGAM/SIMGE).

A considerable seasonal temperature variation was shown (Table 2), with the lowest value $\left(12.7^{\circ} \mathrm{C}\right)$ registered during the dry season (winter) in Caraça river.

This river also exhibited the lowest $\mathrm{pH}$ values (4.0) and the highest concentrations of dissolved oxygen $(9.9 \mathrm{mg} / \mathrm{L})$. Ipanema river showed the lowest concentration of oxygen $(<2.0 \mathrm{mg} / \mathrm{L})$ and the highest conductivity $(375 \mu \mathrm{S} / \mathrm{cm})$ and alkalinity values $(2.1$ meqCO $\left.\mathrm{CO}_{2} / \mathrm{L}\right)$. Chlorophyll- $a$ concentrations were low in all rivers $(0.7-27.5 \mu \mathrm{g} / \mathrm{L})$, except in Severo river during the rainy season, when the highest value was observed $(53.5 \mu \mathrm{g} / \mathrm{L})$. Ipanema river showed the highest values of total-N $(5,988 \mu \mathrm{g} / \mathrm{L}), \quad \mathrm{NH}_{4}-\mathrm{N}$ $(3,320 \mu \mathrm{g} / \mathrm{L})$, total-P $(843 \mu \mathrm{g} / \mathrm{L}), \mathrm{PO}_{4}-\mathrm{P}(455 \mu \mathrm{g} / \mathrm{L})$, silica $(5.5 \mathrm{mg} / \mathrm{L})$ and DOC $(13.7 \mathrm{mg} / \mathrm{L})$ and among the sampled rivers, it showed the highest impact possibly due to the deposition of untreated domestic and industrial effluents (Table 3). Caraça river, on the other hand, was considered the most preserved environment, presenting low values of total-N $(48.6 \mu \mathrm{g} / \mathrm{L}), \mathrm{NH}_{4}-\mathrm{N}(5.4 \mu \mathrm{g} / \mathrm{L})$, total-P $(4.7 \mu \mathrm{g} / \mathrm{L})$ and $\mathrm{PO}_{4}-\mathrm{P}(2.0 \mu \mathrm{g} / \mathrm{L})$.

The stechiometrical ratios between total nitrogen and total phosphorus (N/P) during the rainy season, only in the first year, suggest a limitation by nitrogen (N/P < 9, according to Vollenweider, 1983 in Salas and Martino, 1991), except in Caraça river, where high ratios in both sampling years $(\mathrm{N} / \mathrm{P}=97.7$ and 52.8) were registered. During the two dry seasons, higher N/P ratios were observed in all of the rivers, showing a limitation by phosphorus, except in Ipanema $(\mathrm{N} / \mathrm{P}=7.4$ and 7.1 respectively) and Caraça rivers $(\mathrm{N} / \mathrm{P}=4.4)$. 


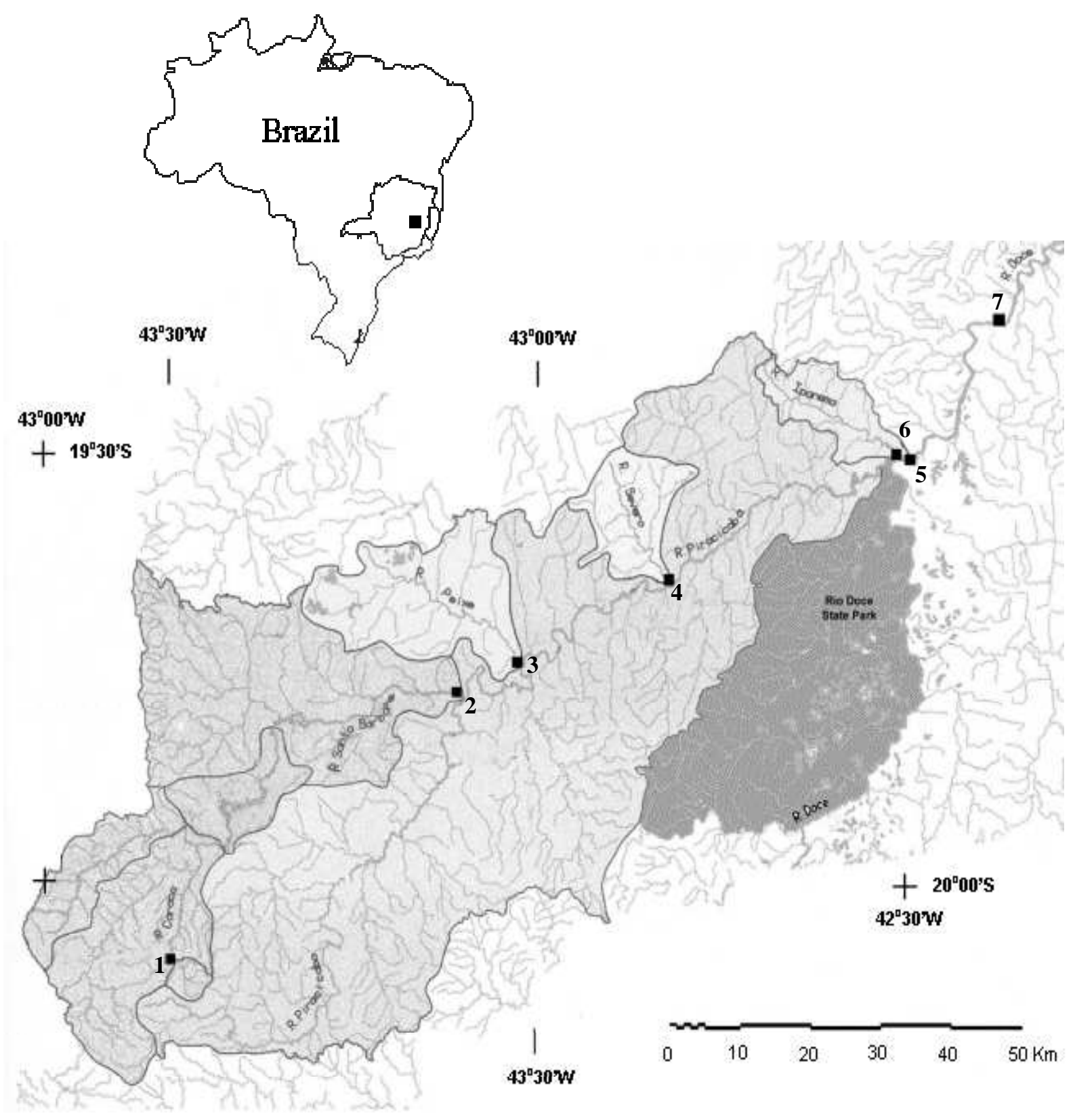

Source: Paula et al. (1997) modified.

Figure 1 - Location of the sub-basin and respective sampling stations (1- Caraça, 2- Santa Bárbara, 3- Peixe, 4- Severo, 5- Piracicaba, 6- Ipanema and 7- Doce) in the middle Rio Doce basin, Minas Gerais State-Brazil. 
Table 2 - Abiotic variables (maximum and minimum values of temperature, $\mathrm{pH}$, eletric conductivity, dissolved oxygen, alkalinity, chlorophyll- $a$ and dissolved organic carbon) of the sub-basins of the middle Rio Doce basin, during the rainy and dry seasons of 2000 and 2001.

\begin{tabular}{l|c|c|c|c|c|c|c}
\hline Rivers & $\begin{array}{c}\text { Temp. } \\
\mathbf{0} \mathbf{C}\end{array}$ & $\mathbf{p H}$ & $\begin{array}{c}\mathbf{C o n d} \\
\boldsymbol{\mu S} / \mathbf{c m}\end{array}$ & $\begin{array}{c}\mathbf{D . O} . \\
\mathbf{m g} / \mathbf{L}\end{array}$ & $\begin{array}{c}\text { Alkal } \\
\mathbf{m e q} / \mathbf{L}\end{array}$ & $\begin{array}{c}\text { Chlo. } \\
\boldsymbol{\mu g} / \mathbf{L}\end{array}$ & $\begin{array}{c}\text { DOC } \\
\mathbf{m g} / \mathbf{L}\end{array}$ \\
\hline Rainy & $\mathbf{M i n}-\mathbf{M a x}$ & $\mathbf{M i n}-\mathbf{M a x}$ & $\mathbf{M i n}-\mathbf{M a x}$ & $\mathbf{M i n}-\mathbf{M a x}$ & $\mathbf{M i n}-\mathbf{M a x}$ & $\mathbf{M i n}-\mathbf{M a x}$ & $\mathbf{M i n}-\mathbf{M a x}$ \\
\hline Caraça & $16.0-19.3$ & $4.0-5.2$ & $9.0-16.0$ & $6.5-9.9$ & 0.0 & $2.9-3.7$ & $3.9-12.4$ \\
Sta. & $23.1-25.6$ & $6.6-7.0$ & $39.0-58.3$ & $5.0-9.8$ & $0.1-0.4$ & $6.4-8.6$ & $2.2-3.6$ \\
Bárbara & & & & & & & \\
Peixe & $22.0-24.8$ & $6.4-7.5$ & $62.0-63.0$ & $6.2-8.7$ & $0.2-0.4$ & $7.5-18.7$ & $2.5-7.5$ \\
Severo & $22.8-24.5$ & $6.5-7.4$ & $25.5-26.0$ & $6.2-9.3$ & $0.1-0.3$ & $2.7-53.5$ & $1.8-10.0$ \\
Piracicaba & $26.4-27.5$ & $7.1-7.6$ & $75.0-120.4$ & $3.8-7.6$ & $0.2-0.5$ & $1.6-20.3$ & $2.7-4.3$ \\
Ipanema & $27.1-29.0$ & $7.4-7.5$ & $283.0-375.4$ & $0.8-2.0$ & $0.7-2.1$ & $2.7-4.3$ & $9.3-13.7$ \\
Doce & $26.6-28.3$ & $6.8-7.6$ & $54.0-107.8$ & $5.4-9.0$ & $0.2-0.5$ & $6.4-15.5$ & $3.2-4.0$ \\
\hline \multicolumn{1}{c}{ Dry } & & & & & & & \\
Caraça & $12.7-17.9$ & $5.2-6.6$ & $1.0-9.2$ & 7.7 & 0.0 & 5.1 & 1.9 \\
Sta. & $19.3-22.1$ & $6.8-6.9$ & $6.0-61.5$ & $5.6-7.6$ & 0.4 & 3.7 & 0.9 \\
Bárbara & & & & & & & 1.6 \\
Peixe & $15.4-19.8$ & $6.4-6.6$ & $9.0-57.9$ & $6.1-7.6$ & 0.4 & 0.3 & 1.5 \\
Severo & $15.5-19.3$ & $6.3-6.4$ & $2.0-27.9$ & $3.2-7.9$ & 0.3 & 5.9 & 0.7 \\
Piracicaba & $21.6-26.1$ & $6.8-6.9$ & $121.5-148.0$ & 7.3 & 0.4 & 27.5 & 1.9 \\
Ipanema & $25.9-27.0$ & $6.8-7.3$ & $322.0-356.0$ & $0.3-0.4$ & 1.7 & 0.7 & 9.3 \\
Doce & $21.9-23.9$ & 6.6 & $88.8-101.0$ & $3.2-8.2$ & 0.4 & 8.6 & 1.7 \\
\hline
\end{tabular}

The countings of total and faecal coliforms were higher in general during the rainy season (Table 4 ). The highest densities of total coliforms were recorded in rivers Piracicaba and Ipanema ( $>160$ $\left.\mathrm{x} 10^{3} \mathrm{MPN} / 100 \mathrm{~mL}\right)$ and the lowest countings, in river Caraça $\left(<2 \times 10^{3} \mathrm{MPN} / 100 \mathrm{~mL}\right)$. For faecal coliforms the same variation was observed, with the highest values recorded in river Ipanema (> $160 \mathrm{x} 10^{3} \mathrm{MPN} / 100 \mathrm{~mL}$ ) and the lowest countings in river Caraça $\left(<2 \times 10^{3}\right.$ MPN/100mL). The highest values for heterotrophic bacteria were registered during the rainy season in rivers Santa Bárbara, Peixe and Severo $\left(300 \times 10^{5} \mathrm{CFU} / \mathrm{mL}\right)$. The highest yeasts countings was recorded in Piracicaba river (460 $\mathrm{CFU} / \mathrm{mL}$ ) during the dry season and in Severo river $(190 \mathrm{CFU} / \mathrm{mL}$ ) during the rainy season.

The characterization of the trophic status according to the classification proposed by Salas and Martino (1991) is shown in Table 4. The results showed a clear seasonal variation in the trophic status for the majority of the studied rivers, except for Ipanema river, which was characteristically hyper-eutrophic and Caraça river, a typical oligotrophic environment, during both seasons (Table 5). Rivers Peixe, Piracicaba and Doce could be classified as eutrophic during the rainy season and meso-eutrophic during the dry season. Severo river could be considered eutrophic during the rainy season and oligotrophic in the dry season when the quality of its waters who considerably improved. Although they were not quantified in this research, these variations demonstrated the importance of the contributions of allochthonous material and the consequent seasonal variations.

According to linear correlation analyses the variables that presented highest positive correlation with faecal coliforms were total-P and total-N ( $\mathrm{r}>0.80$ ). The first two axes of the PCA accounted for $69.2 \%$ of the total variance (Fig. 2A). The factor $1(52.3 \%)$ was negatively correlated with dissolved oxygen concentrations and positively correlated with total nitrogen and phosphorus, conductivity and total and faecal coliforms. Axis 2 was positively correlated with heterotrophic bacteria and $\mathrm{pH}$. 
Table 3 - Nutrient concentration (maximum and minimum values) of the sub-basins of the middle Rio Doce basins, during the rainy and dry seasons of 2000 and 2001.

\begin{tabular}{|c|c|c|c|c|c|c|c|}
\hline Rivers & $\begin{array}{l}\text { Tot-P } \\
\mu \mathrm{g} / \mathrm{L}\end{array}$ & $\begin{array}{c}\mathrm{PO}_{4}-\mathrm{P} \\
\mu \mathrm{g} / \mathrm{L}\end{array}$ & $\begin{array}{l}\text { Tot-N } \\
\mu \mathrm{g} / \mathrm{L}\end{array}$ & $\begin{array}{c}\mathrm{NH}_{4}-\mathrm{N} \\
\mu \mathrm{g} / \mathrm{L}\end{array}$ & $\begin{array}{c}\mathrm{NO}_{3}-\mathrm{N} \\
\mu \mathrm{g} / \mathrm{L}\end{array}$ & $\begin{array}{c}\mathrm{NO}_{2}-\mathrm{N} \\
\mu \mathrm{g} / \mathrm{L}\end{array}$ & $\mathbf{N} / \mathbf{P}$ \\
\hline Rainy & Min - Max & Min - Max & Min - Max & Min - Max & Min - Max & Min - Max & Min - Max \\
\hline Caraça & $4.7-6.7$ & $2.0-3.8$ & $351.5-461.3$ & $16.9-18.3$ & $9.0-16.1$ & $1.9-4.2$ & $52.8-97.7$ \\
\hline Sta. Bárbara & $17.4-136.9$ & $1.3-6.2$ & $393.4-849.5$ & $20.6-129.5$ & $43.9-132.9$ & $3.8-8.5$ & $6.2-22.6$ \\
\hline Peixe & $52.9-170.8$ & $11.1-19.3$ & $1,181-1,358$ & $26.3-473.3$ & $87.5-337.5$ & $13.6-171.0$ & $8.0-22.3$ \\
\hline Severo & $14.7-469.7$ & $1.2-7.8$ & $234.1-1,836$ & $9.4-32.6$ & $23.3-68.3$ & $2.9-3.5$ & $3.9-15.8$ \\
\hline Piracicaba & $80.2-240.3$ & $10.8-11.8$ & $1,197-1,217$ & $67.2-308.3$ & $140.8-702.9$ & $9.5-12.7$ & $5.0-15.1$ \\
\hline Ipanema & $772.7-812.6$ & $68.7-210.2$ & $5,341-5,491$ & $1,557-3,320$ & $11.9-41.5$ & $2.7-28.3$ & $6.8-6.9$ \\
\hline Doce & $63.9-318.3$ & $5.0-63.9$ & $873.2-1,240$ & $23.5-235.8$ & $92.4-283.5$ & $6.4-6.9$ & $3.9-13.7$ \\
\hline \multicolumn{8}{|l|}{ Dry } \\
\hline Caraça & $7.6-10.8$ & 3.2 & $48.1-103.8$ & $5.4-14.2$ & $8.2-28.8$ & $1.6-1.8$ & $4.4-13.6$ \\
\hline Sta. Bárbara & $16.8-25.2$ & $4.2-6.2$ & $284.3-372.3$ & $15.8-27.6$ & $16.8-167.3$ & $2.9-3.6$ & $14.8-17.0$ \\
\hline Peixe & $95.8-125.5$ & $62.1-73.5$ & $1,894-1,957$ & $192.0-369.1$ & $43.5-902.9$ & $76.8-193.2$ & $15.9-19.8$ \\
\hline Severo & $22.8-25.9$ & $3.6-9.7$ & $226.0-277.7$ & $5.5-30.1$ & $15.3-122.4$ & $2.0-2.4$ & $9.9-10.7$ \\
\hline Piracicaba & $84.9-105.9$ & $18.5-23.7$ & $1,621-1,842$ & $236.1-279.7$ & $137.5-721.7$ & $28.2-30.8$ & $15.3-21.7$ \\
\hline Ipanema & $760.7-843.3$ & $351.3-455.5$ & $5,641-5,988$ & $1,063-1,547$ & $1.5-7.8$ & $7.3-17.1$ & $7.1-7.4$ \\
\hline Doce & $61.0-68.7$ & $18.2-29.7$ & $691.6-806.8$ & $55.5-77.0$ & $26.2-312.4$ & $6.3-7.7$ & $11.3-11.7$ \\
\hline
\end{tabular}

The first principal component scores contrasted the rich from poorer rivers, in terms of organic matter, mainly TN and TP (Fig. 2B) and the second principal component scores contrasted the higher and the lower values for heterotrophic bacteria. It was interesting to note the existence of an overlaping among streams sampled in winter and summer. In other words, different seasons were not clearly separated by both axis.

The quality of the waters in the middle Rio Doce:

Due to the several human actions within the watershed (e. g. mining, siderurgy, Eucalyptus plantations, cellulose industry, and discharge of untreated sewage), most water of the middle stretch of Rio Doce were heavily polluted. A particularly interesting example was provided by the sub-basin of Piracicaba river, where the major siderurgy and mining complexes of Minas Gerais state were located. According to CETEC reports (1998), this river received only in 1992 ca. $80,000 \mathrm{~m}^{3}$ of untreated effluents and $c a$. $93,205 \mathrm{Kg} /$ day of total suspended solids, which rendered $c a .71,855 \mathrm{Kg}$ /day of chemical oxygen demand (COD), ca. $9,558 \mathrm{Kg} /$ day of biochemical oxygen demand (BOD), and a toxicity of $c a$. 7,500 equitox/day.

In a previous study conducted in the same sampling areas, Barbosa et al. (1997) found similar values to that measured in this work for temperature, $\mathrm{pH}$, electric conductivity, dissolved oxygen and total alkalinity. However, chlorophyll- $a$ values during both wet and dry periods were lower. The concentrations of nitrogen and phosphorus reported during this previous study were lower than the ones recorded in the present study. The recorded increase in the concentrations of ammonium-nitrogen, soluble reactive phosphorus, and total phosphorus in Ipanema river during both sampled periods deserves attention since they reflect the high loads of untreated sewage of the municipality of Ipatinga. However, this situation could be expected to be reverted soon due to the operation of a sewage treatment plant from September 2001.

Microorganisms and the trophic status of the waters in the middle Rio Doce:

In an attempt to associate information on representative groups of the biota, and stress the use of organisms in the characterization of water quality, the presence of microorganisms (faecal and heterotrophic bacteria) in rivers could be considered as potential indicators of the trophic status of these aquatic ecosystems. Although Huszar et al. (1998) suggested the use of phytoplankton species composition as a more sensitive trophic status definition in lakes, for lotic ecosystems this community was not probably the most appropriated, mainly due to the considerable washout during the rainy season. The recorded data clearly showed the existence of significant correlations (Fig. 2A) between the levels of total phosphorus and nitrogen and faecal coliforms. The inclusion of these microorganisms, as well as heterotrophic bacteria, in 
the characterization of the trophic status was suggested here as a possibility for incorporating some biological information in the current classification of trophic status of streams and rivers. High correlation between total phosphorus and faecal coliforms were also reported by Rosa et al. $(1990 ; 1995)$ and Morais et al. (1996) in lentic environments in the Lagoa Santa plateau, State of Minas Gerais. The observed correlation suggested the possibility of using the variables faecal coliforms and heterotrophic bacteria as complementary parameters, which would allow a better definition of the trophic state of an environment. These biological variables would be particularly important in aquatic systems receiving high organic loads, as demonstrated for the majority of the river stretches within the middle Rio Doce basin, showing high concentrations of total phosphorus and high densities of faecal coliforms and heterotrophic bacteria. An inverse correlation was observed for well-preserved environments that showed lower values of phosphorus, coliforms, and bacteria, here represented by Caraça river.

The present results emphasized the fact that propositions for restoration and conservation measures on river stretches under human impacts must consider the watershed as the unit for studies and interventions. In addition, the definition of the trophic state would be an essential tool for the implementation of any appropriate measure.

Table 4 - Countings (maximum and minimum values) of total and faecal coliforms, yeasts and heterotrophic bacteria of the sub-basins of the middle Rio Doce basins, during the rainy and dry seasons of 2000 and 2001.

\begin{tabular}{|c|c|c|c|c|c|c|c|c|}
\hline \multirow{3}{*}{ Rivers } & \multicolumn{2}{|c|}{\begin{tabular}{|c|} 
Total Coliforms \\
MPN/100ml x 10
\end{tabular}} & \multicolumn{2}{|c|}{\begin{tabular}{|l|} 
Faecal Coliforms \\
MPN/100ml x 10 \\
\end{tabular}} & \multicolumn{2}{|c|}{$\begin{array}{c}\text { Yeasts } \\
\text { CFU/ml }\end{array}$} & \multicolumn{2}{|c|}{$\begin{array}{c}\text { Heterotrophic Bacteria } \\
\text { CFU/ml } \times 10^{5}\end{array}$} \\
\hline & Rainy & Dry & Rainy & Dry & Rainy & Dry & Rainy & Dry \\
\hline & Min - Max & Min - Max & Min - Max & Min - Max & Min - Max & Min - Max & Min - Max & Min - Max \\
\hline Caraça & N.D - 2 & $<2-4$ & N.D - <2 & $<2-2$ & N.D & $3-15$ & N.D & N.D - 74 \\
\hline Sta. Bárbara & $<2-28$ & $<2-22$ & $2-22$ & $<2-2$ & N.D - 30 & N.D - 390 & $75->300$ & $70-73$ \\
\hline Peixe & $<2-\geq 160$ & 7 & $<2-30$ & $1.1-2$ & N.D - 20 & $2-3$ & $18->300$ & $2.3-179$ \\
\hline Severo & $\geq 160$ & $2-8$ & 160 & $<2-7$ & $33-190$ & $10-26$ & $48->300$ & $2.3-50$ \\
\hline Piracicaba & 160 & N.D - $\geq 160$ & $3.4-50$ & N.D - 9 & N.D - 16 & N.D - 460 & N.D - 49 & N.D - 59 \\
\hline Ipanema & $\geq 160$ & $\geq 160$ & 160 & $35-160$ & $10-43$ & $6-393$ & $78-160$ & $47.3->300$ \\
\hline Doce & $24-30$ & $3.4-30$ & $8-30$ & $3.4-22$ & $6-10$ & $6-26$ & $20-64$ & $34-85$ \\
\hline
\end{tabular}

$*$ N.D $=$ Not detected

Table 5 - Trophic state classification of the sub-basins of the middle Rio Doce, according to the model proposed by Salas and Martino (1981).(in brackets, limits for the trophic categories of total phosphorus concentration).

\begin{tabular}{|c|c|c|c|c|c|c|}
\hline \multirow{3}{*}{ Rivers } & \multicolumn{6}{|c|}{ Trophic State (Salas and Martino, 1991) } \\
\hline & \multicolumn{2}{|c|}{ Oligotrophic $(\mathbf{2 3 , 1})$} & \multicolumn{2}{|c|}{ Mesotrophic $(39,6)$} & \multicolumn{2}{|c|}{ Eutrophic $(118,7)$} \\
\hline & Rainy & Dry & Rainy & Dry & Rainy & Dry \\
\hline Caraça & $4.7-6.7$ & $7.6-10.8$ & & & & \\
\hline Sta. Bárbara & 17.4 & $16.8-25.2$ & & & 136.9 & \\
\hline Peixe & & & 52.9 & 95.8 & 170.8 & 125.5 \\
\hline Severo & 14.7 & $22.8-25.9$ & & & 469.7 & \\
\hline Piracicaba & & & 80.2 & $84.9-105.9$ & 240.3 & \\
\hline Ipanema & & & & & $772.7-812.6$ & $760.7-843.3$ \\
\hline Doce & & & 63.9 & $61.0-68.7$ & 318.3 & \\
\hline
\end{tabular}



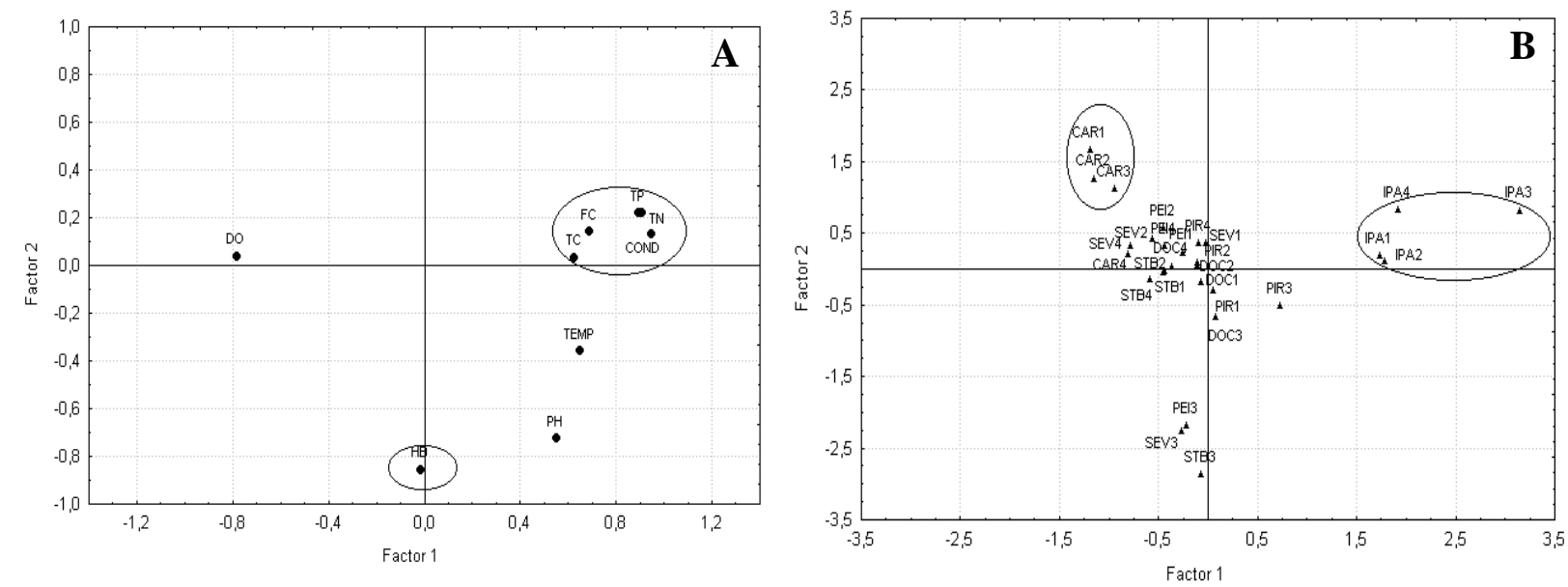

Figure 2 - Correlations of biotic and abiotic parameters with the first two axes of principal component analysis (A) and score distributions of streams sampled in different seasons along the first two principal components axes (B).

TEMP=temperature; $\mathrm{COND}=$ Conductivity; $\mathrm{DO}=$ Dissolved oxygen; $\mathrm{TP}=\mathrm{Total}$ phosphurus; $\mathrm{TN}=$ Total nitrogen; $\mathrm{FC}=$ faecal coliforms; $\mathrm{TC}=$ total coliforms; $\mathrm{HH}=$ heterotrophic bacteria;

CAR=Caraça; STB=Santa Bárbara; PEI=Peixe;SEV=Severo; PIR=Piracicaba; IPA=Ipanema; DOC $=$ Doce.

$1=$ rainy $2000 ; 2=\operatorname{dry} 2000 ; 3=$ rainy $2001 ; 4=\operatorname{dry} 2001$.

\section{RESUMO}

A concentração de fósforo total foi utilizada para determinar o grau de trofia das principais sub-bacias do trecho médio da bacia do Rio Doce, em Minas Gerais, e variáveis físicas, químicas e microbiológicas da água foram analisadas nos períodos de chuva e seca durante os anos de 2000 e 2001. O estudo visou determinar mudanças na qualidade da água causadas pela sazonalidade e por diferentes atividades antrópicas. As áreas estudadas variaram de oligotróficas a eutróficas. As variáveis que apresentaram as maiores correlações positivas com a densidades de coliformes fecais foram as concentrações de nitrogênio e fósforo total, além disso, bactérias heterotróficas mostrou-se capaz de diferenciar os ambientes. Estes resultados sugerem a inclusão do grau de trofia e da caracterização das atividades antrópicas na bacia, como ferramentas importantes para a proposição de medidas de recuperação e conservação de trechos de rios sujeitos a impactos antrópicos.

\section{ACKNOWLEDGEMENTS}

This research was supported by PADI Foundation, Project AWARE, PADCT/CNPq (process number 62.0477/98.9) and the Brazil Long Term Ecological Research (Pesquisas Ecológicas de Longa Duração PELD/CNPq). Special thanks to Dr. Adlane Ferreira (Depto Biologia Geral, ICB/UFMG) for the English corrections.

\section{REFERENCES}

Barbosa, F. A. R. and Callisto, M. (2000), Rapid assessment of water quality and diversity of benthic macroinvertebrates in the upper and middle Paraguay river using the Aqua-RAP approach. Verh. Internat. Verein Limnol., 27 : (5), 2688-2692.

Barbosa, F. A. R; Souza, E. M. M.; Vieira, F.; Renault, G. P. C. P.; Rocha, L. A.; Maia-Barbosa, P. M.; Oberdá, S. M. and Mingoti, S. A. (1997), Impactos antrópicos e biodiversidade aquática. In: Paula, J. A. (Coord.). Biodiversidade, População e Economia: uma região de Mata Atlântica. UFMG/CEDEPLAR, ECMVS; PADTC/CIAMB. Belo Horizonte : Rona Editora. pp. 345-454. 
Centro de Tecnologia de Minas Gerais - CETEC. (1998), Levantamento da poluição hídrica da bacia do Rio Piracicaba. Relatório Final, Belo Horizonte.

Golterman, H. L.; Clymi, R. S. and Ohmstad, A. M. (1978), Methods for Physical and Chemical Analysis of Fresh Water. Oxford : Blackwell Scientific Publ. 214 pp.

Gordon, N. D.; Mchahon, T. A. and Calow, P. (1998), Stream Hydrology, an Introduction for Ecologists, In: Dobson, M. and Frid, C. (Eds). Ecology of Aquatic Systems. England : Longman. $222 \mathrm{pp}$.

Grasshoff, K. (1976) Methods of Seawater Analysis. Verlag Chemie. New York : Weinheim. 317 pp.

Greenberg, A. E.; Clesceri, L. S. E. and Eaton, A. D. (1998), Standad methods for the examination of water and waste water. $20^{\text {th }}$ ed. Washington : APHA. 1268 pp.

Hagler, A. N. and Ahearn, D. G. (1997), Ecology of Aquatic yeast. In: Rose, A. N. and Harison, J. S. (Eds). The yeasts: Biology of yeasts. London : Academic Press. pp. 181-205

Hagler, A. N. and Mendonça-Hagler, L. C. (1981), Yeasts from marine and estuarine water with different levels of pollution in the state of Rio de Janeiro, Brazil. Appl. Environ. Microbiol., 44, 173-178.

Huszar, V. L. M.; Silva, L. H. S.; Domingos, P. Marinho, M. and Melo, S. (1998), Phytoplankton species composition is more sensitive than OECD criteria to the trophic status of three Brazilian tropical lakes. Hydrobiologia, 369/370, 59-71.

Kelly, M. G. and Whitton, B. A. (1998), Biological monitoring of eutrophication in rivers. Hydrobiologia, 384, 55-67.

Kurtzman, C. P. and Fell, J. W. (1998), The Yeast: a taxonomic study. $4^{\text {th }}$ ed. Elsevier Amsterdam. $1074 \mathrm{pp}$.

Lorenzen, C. J. (1967), Determination of chlorophyll and pheopigments: Spectrophotometric equations. Limnol. Oceanogr. 12, 343-346.

Mackereth, F. J. H.; Heron, J. and Talling, J. F. (1978), Water analysis: some revised methods for limnologists. (scientific publication $n^{\circ} 36$ ) Freshwater Biological Association, Cumbria and Dorset, England. 117 pp.

Morais, P. B.; Resende, M. A.; Rosa, C. A. and Barbosa, F. A. R. (1996), Occurrence and diel distribution of yeasts in a Paleo-karstic lake of southeastern Brazil. Rev. Microbiol., 27, 182-188.

OECD. (1982), Eutrophication of waters. Monitoring, assessment and control. Paris : OECD. 154 pp.
Paula, J. A.; Barbieri, A. F.; Guerra, C. B.; Landau, E. C.; Vieira, F.; Barbosa, F. A. R.; Costa, H. S. M.; Guerra, L. P.; Monte-Mór, R. L. M.; Simões, R. F. and Braga, T. M. (1997), Biodiversidade, população e economia: uma região de Mata Atlântica. UFMG/CedeplarECMVS; PADCT/CIAMB, Belo Horizonte : Rona Editora. 672 pp.

Rosa, C. A.; Resende, M. A.; Barbosa, F. A. R.; Morais, P. B. and Franzot, S. P. (1995), Yeast diversity in a mesotrophic lake on the karstic plateau of Lagoa Santa, MG-Brazil. Hydrobiologia, 308, 103-108.

Rosa, C. A.; Resende, M. A.; Franzot, S. P.; Morais, P. B. and Barbosa, F. A. R. (1990), Distribuição de leveduras em um lago do karst do planalto de Lagoa Santa-MG, Rev. Brasil. Microbiol., 21 : (1), 19-24.

Salas, H. J. and Martino, P. (1991), A simplified phosphorus trophic state model for warm-water tropical lakes. Wat. Res., 25, 341-350.

Simard, R. E. (1971), Yeasts as an indicator of pollution. Mar. Poll. Bull., 8, 123-125.

Tundisi, J. G. and Barbosa, F. A. R. (1995), Conservation of aquatic ecosystem: present status and perspectives. In: Limnology in Brazil. ABC/SBL. Rio de Janeiro : Graftex Comunicação Visual. pp.365-371.

Wetzel, R. G. (1991), On the teaching of limnology: Need for a national initiative. Limnol. Oceonogr., 36 : (1), 213-215.
Received: November 10, 2003; Revised: May 17, 2004; Accepted: November 18, 2004. 